\title{
Analisis Gaya Belajar Peserta Didik Kelas V Sekolah Dasar
}

\author{
Saringah $^{1}$, Sri Dewi ${ }^{2}$ \\ ${ }^{1,2}$ Sekolah Dasar Negeri 016, Serusa, Indonesia
}

\begin{tabular}{l}
\hline \hline Article Info \\
\hline Article history: \\
Received Jun 29, 2020 \\
Revised Ags 7, 2020 \\
Accepted Sep 28, 2020 \\
\hline
\end{tabular}

\section{Keywords:}

Gaya Belajar

Peserta Didik

Sekolah Dasar

\begin{abstract}
ABSTRAK
Tujuan Penelitian: Penelitian ini bertujuan untuk mengetahui gaya belajar peserta didik kelas V SD Negeri 016 Serusa.

Metode Penelitian: Penelitian ini menggunakan metode penelitian kombinasi (mixed method) model atau desain sequential explanatory. Populasi dalam penelitian ini yaitu semua peserta didik kelas $\mathrm{V}$ yang berjumlah 26 siswa. Sampel penelitian metode kuantitatif ini mengambil seluruh siswa dan untuk metode kualitatif mengambil 3 peserta didik sebagai subjek penelitian. Data dikumpulkan menggunakan angket, wawancara, dan observasi. Teknik analisis data yang digunakan pada penelitian metode kuantitatif yaitu menggunakan persentase dan pada metode kualitatif menggunakan teknik analisis data model Miles and Huberman.
\end{abstract}

Temuan Utama: Hasil penelitian menunjukkan bahwa gaya belajar peserta didik kelas V SD Negeri 016 Serusa menggunakan tiga kombinasi gaya belajar VAK (visual, auditori, kinestetik) dan dari ketiga gaya belajar tersebut sebanyak 10 peserta didik atau $38,4 \%$ peserta didik menggunakan kecenderungan gaya belajar visual, 5 peserta didik atau 19,2\% menggunakan kecenderungan gaya belajar auditori, 4 peserta didik atau 15,3\% menggunakan kencenderungan gaya belajar kinestetik, 4 peserta didik atau $15,3 \%$ menggunakan kecenderungan gaya belajar visual-auditori, 1 peserta didik atau 3,8\% menggunakan kecenderungan gaya belajar auditorikinestetik, 1 peserta didik atau 3,8\% menggunakan kecenderungan gaya belajar visual-kinestetik, dan 1 peserta didik atau 3,8\% menggunakan kecenderungan gaya belajar visual-auditori-kinestetik. Data yang diperoleh melalui metode kualitatif menguatkan data yang diperoleh dari metode kuantitatif.

Keterbaruan Penelitian: Keterbaruan penelitian ini dilihat dari instrument yang digunakan serta sampel yang digunakan.

This is an open access article under the $\mathrm{CC} B Y-N C$ license

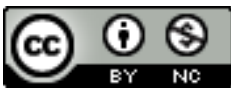

\section{Corresponding Author:}

Saringah

Sekolah Dasar Negeri 16, Serusa, Indonesia

Email: saringah@gmail.com

\section{PENDAHULUAN}

Pendidikan merupakan suatu pengalaman yang harus dialami oleh setiap individu agar mereka dapat menyesuaikan dan menempatkan diri dengan lingkungan masyarakat. Pendidikan membuat setiap individu belajar mengenal dan memahami tentang pentingnya kehidupan. Sejak dulu sampai sekarang pendidikan selalu mengharapkan dapat menghasilkan lulusan yang berkualitas, baik dari segi keilmuan maupun segi keimanan. Pendidikan Nasional berfungsi mengembangkan potensi peserta didik agar menjadi manusia yang beriman dan bertakwa kepada Tuhan Yang Maha Esa, berakhlak mulia, sehat, berilmu, bercakap, kreatif, mandiri dan menjadi warga negara yang demokratis serta bertanggung jawab[1]. Upaya untuk mendapatkan 
itu semua maka setiap individu (peserta didik) harus menempuh suatu pendidikan, yang tentunya di dalamnya terdapat proses pembelajaran. Selama proses pembelajaran terdapat suatu transfer ilmu dari seorang guru kepada peserta didik atau sebaliknya, sehingga peserta didik diharapkan memiliki ilmu pengetahuan yang luas dalam pendidikan dan dapat meningkatkan prestasi belajarnya.

Prestasi belajar merupakan hasil yang dicapai seorang peserta didik setelah mengikuti proses pembelajaran. Prestasi belajar merupakan keseluruhan hasil belajar peserta didik secara kognitif, afektif, dan psikomotor[2]. Prestasi belajar ranah kognitif merupakan prestasi dalam bidang pengetahuan/akademik, prestasi ranah afektif merupakan prestasi dalam bidang sikap, dan prestasi ranah psikomotor merupakan prestasi dalam bidang keterampilan. Ciri yang menunjukkan keberhasilan belajar seorang peserta didik adalah prestasi akademiknya di sekolah [3]. Peserta didik yang berprestasi akademik menunjukkan nilai-nilai di atas batas minimal prestasi belajar. Indikator prestasi belajar secara akademik ditetapkan melalui nilai kelulusan belajar pada mata pelajaran. Kelulusan belajar (passing grade) peserta didik yang berprestasi akademik minimal sama dengan tujuh puluh dalam norma skala angka dari nol sampai seratus untuk pelajaran-pelajaran inti (core subject) karena bidang studi inti merupakan kunci pengetahuan lain [4]. Prestasi akademik dapat dipersiapkan semenjak awal pembelajaran oleh peserta didik. Ada berbagai faktor yang mempengaruhi prestasi akademik peserta didik. Prestasi akademik yang dicapai seseorang merupakan hasil interaksi berbagai faktor yang mempengaruhinya baik dari dalam diri (faktor internal) maupun dari luar diri (faktor eksternal) individu. Adapun yang termasuk faktor dari diri peserta didik itu sendiri adalah gaya belajarnya [5].

Gaya belajar adalah cara yang konsisten yang dilakukan oleh seorang murid dalam menangkap stimulus atau informasi, cara mengingat, berpikir, dan memecahkan soal [6]. Gaya berpikir dan belajar (learning and thinking styles) bukanlah kemampuan, tetapi cara yang disukai untuk menggunakan kemampuan seseorang [7]. Memahami gaya belajar peserta didik memudahkan guru dalam menentukan strategi-strategi untuk menyusun pembelajaran, supaya pembelajaran yang dirancang guru tidak monoton dan lebih bervariasi, sehingga peserta didik akan menjadi pelajar yang lebih percaya diri dan lebih puas dengan kemajuan belajar mereka. Ada berbagai pendekatan dalam gaya belajar. Ada dua pendekatan gaya belajar yang dikenal luas di Indonesia, yakni pendekatan kecerdasan majemuk (Multiple Intelligence) Howard Gardner dan pendekatan preferensi sensori yang terdiri dari gaya belajar visual, gaya belajar auditorial, dan gaya belajar kinestetik [8]. Gaya belajar visual mengandalkan indera visual dalam menerima dan mengolah informasi dan mudah membayangkan apa yang dibicarakan, gaya belajar auditorial mengandalkan pendengaran sebagai alat komunikasi internal maupun eksternal serta mudah bercerita, sedangkan gaya belajar kinestetik menggunakan sensasi sentuhan dan gerak dalam belajar sehingga sulit untuk duduk diam dalam waktu yang relatif lama [9].

Kesesuaian antara gaya mengajar guru dengan gaya belajar peserta didik mempengaruhi keefektifan belajar peserta didik. Dari setiap 30 peserta didik, 22 di antaranya rata-rata dapat belajar secara efektif selama gurunya menghadirkan kegiatan belajar yang berkombinasi antara visual, auditori dan kinestetik [10]. Dengan demikian, keselarasan gaya mengajar guru dengan gaya belajar peserta didik dapat meningkatkan keefektifan belajar yang mana akan mempengaruhi pula pada prestasi akademik peserta didik. mengabaikan gaya belajar peserta didik sehingga kurang mengakomodasi gaya belajar peserta didik dalam metode pembelajaran. Prestasi akademik antar peserta didik bervariasi antara tujuh puluh hingga sembilan puluh. Seharusnya dengan metode dan guru yang sama akan dihasilkan variasi nilai yang tidak terpaut jauh. Peserta didik kelas $\mathrm{V}$ belajar tidak dengan satu macam gaya. Ada peserta didik yang senang melakukan aktivitas fisik, tetapi lebih nyaman jika suasana belajar tenang. Ada pula peserta didik yang senang berbicara ketika belajar [11]. Dapat disimpulkan peserta didik kelas V memiliki gaya belajar yang bervariasi tidak dengan satu macam gaya belajar saja [12]. Berdasarkan permasalahan gaya belajar di atas, peneliti tertarik untuk mengetahui gaya belajar peserta didik kelas V SD Negeri 016 Serusa yang didasarkan pada model gaya belajar Visual, Auditori, dan Kinestetik (VAK). Penelitian ini diharapkan mampu memberi gambaran kepada guru tentang bagaimana gaya belajar peserta didik, sehingga nantinya guru mampu menyusun pembelajaran yang disesuaikan dengan gaya belajar peserta didiknya.

Peneliti melakukan studi pendahuluan kepada guru dan peserta didik kelas V SD Negeri 016 Serusa, Sokaraja, Banyumas, Jawa Tengah. Selama melakukan studi pendahuluan peneliti mengamati gaya belajar peserta didik saat proses pembelajaran di dalam kelas. Ketika mencatat pelajaran, ada peserta didik yang gaduh menabuh meja dan bernyanyi, ada yang berteriak menyuruh temannya diam karena ia tidak bisa berkonsentrasi, ada yang berjalan-jalan, ada yang asyik berbicara dengan teman sebangku, dan ada yang diam menyangga kepala dengan kedua tangannya. Ada pula peserta didik yang duduk diam dan tidak terpengaruh oleh suasana kelas yang ramai, mencatat materi dengan tenang, hanya sesekali berbicara dengan teman sebangkunya. Dapat disimpulkan bahwa perilaku-perilaku tersebut merupakan cara peserta didik menciptakan lingkungan belajar yang membuat senang, asyik, dan nyaman dengan gaya belajar yang bervariasi. 
Pada saat mengerjakan tugas, banyak peserta didik yang berbicara dengan teman. Beberapa peserta didik tidak dapat duduk diam dan tenang ketika belajar di dalam kelas. Ada peserta didik yang senang berjalan-jalan di dalam kelas dan aktif melakukan pergerakan meskipun ia duduk di tempatnya, ada juga peserta didik yang mengubah-ubah posisi duduknya. Guru kelas V lebih senang menggunakan metode ceramah dan cenderung.

\section{METODE PENELITIAN}

Metode penelitian yang digunakan adalah metode kombinasi (Mixed Methods) model atau desain Sequential Explanatory. Metode kombinasi model atau desain Sequential Explanatory merupakan metode penelitian yang menggabungkan metode penelitian kuantitatif dan kualitatif secara berurutan, di mana pada tahap pertama penelitian dilakukan dengan metode kuantitatif dan pada tahap kedua dilakukan dengan metode kualitatif[13]. Data kuantitatif menggunakan seluruh populasi siswa kelas V SD Negeri 016 Serusa yang berjumlah 26 peserta didik. Data kualitatif mengambil 3 peserta didik sebagai subjek penelitian. Teknik pengumpulan data menggunakan tiga teknik yaitu menggunakan kuesioner atau angket gaya belajar, wawancara dan observasi. Teknik analisis data kuantitatif adalah menggunakan statistik deskriptif. Sedangkan teknik analisis data kuantitatif menggunakan teknik analisis data model Miles and Huberman. Pada saat wawancara peneliti melakukan analisis pada jawaban yang diwawancarai dan apabila dirasa belum memuaskan, peneliti akan meneruskan pertanyaan sampai tahap tertentu dan data dianggap kredibel atau cukup[14]. Data kemudian direduksi untuk memilah-milah hal-hal yang pokok dan mengambil data yang penting, setalah itu data disajikan (display) dengan menyusun kategori-kategori supaya menjadi urut sehingga mudah dipahami dan membuatnya dalam bentuk teks yang bersifat naratif. Data yang telah direduksi dan disajikan kemudian diverifikasi atau menarik kesimpulan untuk membuktikan, memperdalam, memperluas dan menggugurkan data kuantitatif yang telah diperoleh pada tahap awal.

\section{HASIL DAN PEMBAHASAN}

Peneliti dalam menganalisis data angket menggunakan persentase untuk mempersentasekan beberapa gaya belajar yang digunakan peserta didik kelas V SD Negeri 016 Serusa . Berikut merupakan hasil presentase dapat dilihat pada tabel 1.1

Tabel 1. Hasil Perhitungan Persentase Gaya Belajar Peserta Didik Kelas V SD Negeri 016 Serusa

\begin{tabular}{|c|c|c|c|}
\hline \multirow{2}{*}{ Nama } & \multicolumn{3}{|c|}{ Skor } \\
\cline { 2 - 4 } & Visual & Auditori & Kinestetik \\
\hline CF & $87,5 \%$ & $92,5 \%$ & $87,5 \%$ \\
\hline AT & $55 \%$ & $65 \%$ & $62,5 \%$ \\
\hline AGN & $67,5 \%$ & $65 \%$ & $60 \%$ \\
\hline AW & $60 \%$ & $62,5 \%$ & $62,5 \%$ \\
\hline AAP & $67,5 \%$ & $62,5 \%$ & $60 \%$ \\
\hline AMS & $72,5 \%$ & $60 \%$ & $60 \%$ \\
\hline DNF & $62,5 \%$ & $70 \%$ & $62,5 \%$ \\
\hline DM & $80 \%$ & $80 \%$ & $92,5 \%$ \\
\hline DI & $57,5 \%$ & $57,5 \%$ & $57,5 \%$ \\
\hline DWP & $60 \%$ & $62,5 \%$ & $65 \%$ \\
\hline FN & $92,5 \%$ & $87,5 \%$ & $85 \%$ \\
\hline FLX & $60 \%$ & $60 \%$ & $52,5 \%$ \\
\hline FR & $67,5 \%$ & $67,5 \%$ & $65 \%$ \\
\hline GL & $62,5 \%$ & $65 \%$ & $62,5 \%$ \\
\hline KS & $62,5 \%$ & $57,5 \%$ & $70 \%$ \\
\hline MT & $80 \%$ & $77,5 \%$ & $77,5 \%$ \\
\hline MS & $62,5 \%$ & $62,5 \%$ & $65 \%$ \\
\hline ILM & $60 \%$ & $57,5 \%$ & $50 \%$ \\
\hline NA & $70 \%$ & $67,5 \%$ & $60 \%$ \\
\hline RND & $67,5 \%$ & $62,5 \%$ & $62,5 \%$ \\
\hline & & & \\
\hline
\end{tabular}




\begin{tabular}{|c|c|c|c|} 
TK & $65 \%$ & $65 \%$ & $57,5 \%$ \\
\hline TFP & $90 \%$ & $90 \%$ & $85 \%$ \\
\hline AMA & $65 \%$ & $67,5 \%$ & $60 \%$ \\
\hline IRN & $40 \%$ & $37,5 \%$ & $40 \%$ \\
\hline LA & $60 \%$ & $57,5 \%$ & $57,5 \%$ \\
\hline HNG & $95 \%$ & $92,5 \%$ & $80 \%$ \\
\hline
\end{tabular}

Hasil angket pada tabel 1 persentase menunjukkan bahwa dari 26 peserta didik kelas V SD Negeri 016 Serusa memiliki kombinasi dari ketiga gaya belajar yaitu gaya belajar visual, gaya belajar auditori, dan gaya belajar kinestetik. Kecenderungan gaya belajar setiap peserta didik berbeda. Peserta didik memiliki beberapa gaya belajar yang lebih dominan di antara ketiga gaya belajar tersebut. Sebanyak 10 peserta didik memiliki gaya belajar visual, 5 peserta didik lebih dominan memiliki gaya belajar auditori, dan 4 peserta didik dominan memiliki gaya belajar kinestetik.

Selain itu terdapat juga peserta didik yang dominan memiliki dua kombinasi gaya belajar maupun ketiga kombinasi gaya belajar, sebanyak 4 peserta didik memiliki kombinasi gaya belajar visual-auditori, 1 peserta didik memiliki kombinasi gaya belajar auditori-kinestetik, 1 peserta didik memiliki kombinasi gaya belajar visual-kinestetik, dan 1 peserta didik memiliki kombinasi gaya belajar visual-auditori-kinestetik. Berdasarkan data dari hasil angket tersebut diketahui bahwa peserta didik kelas V SD Negeri 016 Serusa yang berjumlah 26 anak masing-masing memiliki kecenderungan gaya belajar yang berbeda-beda satu sama lain. Gaya belajar tersebut adalah gaya belajar visual, auditori dan kinestetik. Sebanyak 10 peserta didik atau 38,4\% peserta didik kelas V SD Negeri 016 Serusa memiliki kecenderungan gaya belajar visual. Sebanyak 5 peserta didik atau 19,2\% peserta didik kelas V SD Negeri 016 Serusa memiliki kecenderungan gaya belajar auditori. Sebanyak 4 peserta didik atau 15,3\% peserta didik kelas V SD Negeri 016 Serusa memiliki kencenderungan gaya belajar kinestetik.

Sedangkan yang memiliki kombinasi dari ketiga gaya belajar adalah sebanyak 4 peserta didik atau 15,3\% peserta didik kelas V SD Negeri 016 Serusa memiliki kecenderungan gaya belajar visual-auditori. Sebanyak 1 peserta didik atau 3,8\% peserta didik kelas V SD Negeri 016 Serusa memiliki kecenderungan gaya belajar auditori-kinestetik. Sebanyak 1 peserta didik atau 3,8\% peserta didik kelas V SD Negeri 016 Serusa memiliki kecenderungan gaya belajar visual-kinestetik. Sebanyak 1 peserta didik atau 3,8\% peserta didik kelas V SD Negeri 016 Serusa memiliki kecenderungan gaya belajar visual-auditori-kinestetik.

Berdasarkan hasil penelitian ini, ada tiga gaya belajar yang cenderung subjek gunakan. FN cenderung pada gaya belajar visual, GL cenderung pada gaya belajar auditori dan DM cenderung pada gaya belajar kinestetik. Berikut merupakan perbandingan banyaknya karakteristik gaya belajar antar peserta didik subjek penelitian. Karakteristik gaya belajar di atas dapat diperjelas melalui tabel 2.

Tabel 2. Intensitas Karakteristik Gaya Belajar

\begin{tabular}{|c|c|c|c|c|c|}
\hline No. & \multirow{2}{*}{$\begin{array}{c}\text { Subjek } \\
\text { Penelitian }\end{array}$} & \multicolumn{3}{|c|}{$\begin{array}{c}\text { Intensitas Karakteristik } \\
\text { Gaya Belajar }\end{array}$} & $\begin{array}{c}\text { Kesimpulan } \\
\text { Dominasi } \\
\text { Gaya } \\
\text { Belajar }\end{array}$ \\
\cline { 3 - 5 } & Visual & Auditori & Kinestetik & Visual \\
\hline 1. & FN & 9 & 6 & 4 & Auditori \\
\hline 2. & GL & 5 & 7 & 5 & Kinestetik \\
\hline 3. & DM & 5 & 7 & 8 & \\
\hline
\end{tabular}

Berdasarkan tabel 2 tersebut, dapat dijelaskan bahwa setiap peserta didik menunjukkan karakteristik ketiga gaya belajar dengan kecenderungan yang berbeda. FN, DM dan GL mempunyai kecenderungan yang tidak sama. Intensitas karakteristik gaya belajar FN meningkat dari gaya belajar kinestetik, auditori dan visual. Intensitas karakteristik gaya belajar GL cenderung dominan ke gaya belajar auditori, dan intensitas gaya belajar visual dan kinestetiknya seimbang. Sedangkan intensitas karakteristik gaya belajar DM meningkat dari gaya belajar visual, gaya belajar auditori dan gaya belajar kinestetik.

Berdasarkan penjabaran hasil penelitian gaya belajar peserta didik di atas, kecenderungan karakteristik gaya belajar visual pada subjek penelitian yakni : a) belajar melalui proses membaca dan menulis, b) tidak pandai memilih kata-kata, c) senang menjawab dengan jawaban singkat, dan d) tempo bicara cepat. Kecenderungan karakteristik gaya belajar auditori pada subjek penelitian yaitu: a) belajar dengan menyimak dan berdiskusi, b) aktif bertanya, dan c) melakukan komunikasi internal. Kecenderungan karakteristik gaya belajar kinestetik adalah: a) aktif bergerak saat belajar, b) aktif menjawab pertanyaan, dan c) antusias mengikuti aktivitas fisik, seperti berolah raga, pramuka, dan bermain drama. Dari berbagai uraian 
di atas, dapat disimpulkan bahwa meskipun peserta didik menggunakan kombinasi gaya belajar visual, auditori, dan kinestetik, tetapi kecenderungan gaya belajarnya berbeda-beda. Ketiga subjek penelitian yaitu FN, GL dan DM memiliki kecenderungan gaya belajar yang berbeda. FN memiliki kecenderungan gaya belajar visual. GL memiliki kecenderungan gaya belajar auditori. Sedangkan DM memiliki kecenderungan gaya belajar kinestetik.

Penelitian ini telah menghasilkan dua temuan. Pertama, peserta didik menunjukkan kombinasi gaya belajar visual, auditori, dan kinestetik (gaya belajar vak). Kedua, peserta didik menunjukkan kecenderungan gaya belajar yang berbeda. Berdasarkan temuan pertama, peserta didik tidak menunjukkan satu gaya belajar saja, melainkan kombinasi gaya belajar visual, auditori dan kinestetik. Subjek belajar tidak hanya dengan membaca saja, tetapi, menulis (membuat catatan materi pembelajaran) sekaligus menyimak apa yang guru sampaikan. Subjek menghafal dengan mengulangi bacaan, senang berdiskusi dengan teman-teman kelas atau bertanya kepada guru, serta aktif melakukan gerak ketika belajar. Temuan ini sesuai dengan pernyataan bahwa peserta didik memiliki kombinasi gaya belajar visual, auditori dan kinestetik, tetapi cenderung pada satu gaya belajar tertentu dibandingkan dua gaya lainnya. Setiap gaya belajar memiliki karakteristik atau ciri khas masing-masing gaya belajar [15].

Peserta didik belajar dengan mendengar, melihat, menulis, menyetuh, dan bergerak. Subjek aktif bertanya dan melakukan diskusi dengan guru dan teman. Subjek senang menunjukkan tangan pertama kali ketika guru bertanya, bermain drama, serta melakukan berbagai aktifitas fisik, seperti mengetukkan jari atau menggerakkan kaki. Tiga gaya belajar dan komunikasi yang berbeda, yaitu: 1) Visual, belajar melalui melihat sesuatu. 2) Auditori, belajar melalui mendengar sesuatu. 3) Kinestetik, belajar melalui aktivitas fisik dan keterlibatan langsung [16]. Secara garis besar mengemukakan karakteristik gaya belajar, adalah: 1) Visual mengandalkan sensori visual, suka mencoret-coret tanpa arti, tempo bicara cepat, dan suka melihat, orang yang rapi dan teratur, mengingat apa yang dilihat, senang menjawab dengan singkat. 2) Auditori suka berbicara sendiri, lebih senang mendengarkan atau lebih banyak berbicara, lebih senang melakukan diskusi, menggerakan bibir saat membaca, senang membaca dengan keras dan mendengarkan, pembicara yang fasih dalam irama yang terpola, mudah terganggu oleh keributan, dan menyukai musik. 3) Kinestetik mengandalkan sensori peraba, banyak beraktivitas fisik, berpikir lebih baik jika bergerak, banyak menggerakkan anggota tubuh saat berbicara, serta merasa kesulitan untuk duduk diam dalam waktu yang relatif lama [17].

Pada temuan kedua, peserta didik menunjukkan perpaduan gaya belajar dengan kecenderungan gaya belajar yang berbeda. Ada peserta didik yang lebih banyak menunjukkan karakteristik gaya belajar auditori, ada yang cenderung menunjukkan gaya belajar visual, tetapi ada pula yang cenderung menunjukkan karakteristik gaya belajar kinestetik. Peserta didik memiliki kombinasi gaya belajar visual, auditori dan kinestetik, tetapi cenderung pada satu gaya belajar tertentu dibandingkan dua gaya lainnya. Setiap gaya belajar memiliki karakteristik atau ciri khas masing-masing gaya belajar [18]. Berdasarkan data dari hasil angket tersebut diketahui bahwa peserta didik kelas V SD Negeri 016 Serusa yang berjumlah 26 anak masing-masing memiliki kecenderungan gaya belajar yang berbeda-beda satu sama lain. Gaya belajar tersebut adalah gaya belajar visual, auditori dan kinestetik. Sebanyak 10 peserta didik atau 38,4\% peserta didik kelas V SD Negeri 016 Serusa memiliki kecenderungan gaya belajar visual. Sebanyak 5 peserta didik atau 19,2\% peserta didik kelas V SD Negeri 016 Serusa memiliki kecenderungan gaya belajar auditori. Sebanyak 4 peserta didik atau 15,3\% peserta didik kelas V SD Negeri 016 Serusa memiliki kencenderungan gaya belajar kinestetik.

Sedangkan yang memiliki kombinasi dari ketiga gaya belajar adalah sebanyak 4 peserta didik atau 15,3\% peserta didik kelas V SD Negeri 016 Serusa memiliki kecenderungan gaya belajar visual-auditori. Sebanyak 1 peserta didik atau 3,8\% peserta didik kelas V SD Negeri 016 Serusa memiliki kecenderungan gaya belajar auditori-kinestetik. Sebanyak 1 peserta didik atau 3,8\% peserta didik kelas V SD Negeri 016 Serusa memiliki kecenderungan gaya belajar visual-kinestetik. Sebanyak 1 peserta didik atau 3,8\% peserta didik kelas V SD Negeri 016 Serusa memiliki kecenderungan gaya belajar visual-auditori-kinestetik. Data hasil observasi dan wawancara dengan 3 (tiga) peserta didik menunjukkan bahwa setiap peserta didik menunjukkan karakteristik ketiga gaya belajar dengan kecenderungan yang berbeda. FN, DM dan GL mempunyai kecenderungan yang tidak sama. Intensitas karakteristik gaya belajar FN meningkat dari gaya belajar kinestetik, auditori dan visual. Intensitas karakteristik gaya belajar GL cenderung dominan ke gaya belajar auditori, dan intensitas gaya belajar visual dan kinestetiknya seimbang. Sedangkan intensitas karakteristik gaya belajar DM meningkat dari gaya belajar visual, gaya belajar auditori dan gaya belajar kinestetik. Dapat disimpulkan bahwa meskipun peserta didik menggunakan kombinasi gaya belajar visual, auditori, dan kinestetik, tetapi kecenderungan gaya belajarnya berbeda-beda. Ketiga subjek penelitian yaitu FN, GL dan DM memiliki kecenderungan gaya belajar yang berbeda. FN memiliki kecenderungan gaya belajar visual. GL memiliki kecenderungan gaya belajar auditori. Sedangkan DM memiliki kecenderungan 
gaya belajar kinestetik. Jadi dapat diketahui bahawa data kualitatif yang diperoleh dengan wawancara membuktikan dan menguatkan data kuantitatif yang didapat melalui angket atau kuesioner.

\section{KESIMPULAN}

Berdasarkan hasil penelitian dan pembahasan pada bab sebelumnya, dapat ditarik kesimpulan bahwa peserta didik menunjukkan gaya belajar VAK (Visual, Auditori, dan Kinestetik). Setiap peserta didik memiliki kecenderungan gaya belajar VAK yang berbeda satu sama lain. Sebanyak 10 peserta didik atau 38,4\% peserta didik kelas V SD Negeri 016 Serusa memiliki kecenderungan gaya belajar visual sebagai gaya belajar yang dominan, 5 peserta didik atau 19,2\% memiliki kecenderungan gaya belajar auditori, 4 peserta didik atau 15,3\% memiliki kencenderungan gaya belajar kinestetik, 4 peserta didik atau 15,3\% memiliki kecenderungan gaya belajar visual-auditori, 1 peserta didik atau 3,8\% memiliki kecenderungan gaya belajar auditori-kinestetik, 1 peserta didik atau 3,8\% memiliki kecenderungan gaya belajar visualkinestetik, dan 1 peserta didik atau 3,8\% memiliki kecenderungan gaya belajar visual-auditori-kinestetik.

\section{UCAPAN TERIMA KASIH}

Terima kasih atas seluruh responden karena telah bersedia menjadi sampel dalam penelitian ini, serta seluruh stakeholder yang barkaitan saya ucapakan terima kasih.

\section{REFERENSI}

[1] Undang-Undang Sistem Pendidikan Nasional Nomor 20 tahun 2003

[2] Syah, M. Psikologi Pendidikan dengan Pendekatan Baru. Bandung: PT Remaja Rosdakarya. 2004

[3] S. Syahrial, A. Asrial, D. A. Kurniawan, P. Nugroho, R. Septiasari, R. A. Pratama, and R. Perdana, "Increased Behavior of Students' Attitudes to Cultural Values Using the Inquiry Learning Model Assisted Ethno constructivism," Journal of Educational Science and Technology (EST), vol. 5, no. 2, pp. 166-175, 2019

[4] Syah, M. Psikologi Pendidikan dengan Pendekatan Baru. Bandung: PT Remaja Rosdakarya. 2004

[5] Ahmadi, H.A. dan Supriyono, W. Psikologi Belajar. Jakarta: Rineka Cipta. 2013

[6] Nasution, S. Berbagai Pendekatan dalam Proses Belajar dan Mengajar. Jakarta: PT Bumi Aksara 2011

[7] Santrock. J.W. Psikologi Pendidikan. Jakarta: Kencana. 2010

[8] D. A. Kurniawan, A. Astalini, D. Darmaji, R. Melsayanti, "Student's Attitude Towards Natural Science," International Journal of Evaluation and Research in Education (IJERE), vol. 8, no. 3, pp. 463-468, 2019

[9] Deporter, B. dan Hernacki, M. Quantum Learning. Bandung: Kaif. 2016

[10] A. Asrial, S. Syahrial, D. A. Kurniawan, F. Chan, P. Nugroho, R. A. Pratama, and R. Septiasari, "Identification: The Effect Of Mathematical Competence On Pedagogic Competency Of Prospective Teacher," Humanities \& Social Sciences Reviews (HSSR), vol. 7, no. 4, pp. 85-92, 2019.

[11] A. Astalini, D. Darmaji, W. Kurniawan, K. Anwar, and D. A. Kurniawan, "Effectivenes of Using E-Module and EAssessment," International Journal of Interactive Mobile Technologies (iJIM), vol. 13, no. 9, pp. 21-39, 2019

[12] A. Asrial, S. Syahrial, D. A. Kurniawan, R. Septiasari, "Hubungan Kompetensi Pedagogik Dengan Kompetensi IPA Mahasiswa Pendidikan Guru Sekolah Dasar,” Pedagogia: Jurnal Penididikan, vol. 8, no. 2, pp. 149-157, 2019

[13] Sugiyono. Metode Penelitian Kombinasi. Bandung: Alfabeta. 2014

[14] Sugiyono,Metode Penelitian Kuntitatif,Kualitatif dan $R \&$ D..h. 145

[15] Rose, C. Dan Nicholl, M. J. Accelerated Learning. Bandung: Nuansa. 2002

[16] Rose, C. Dan Nicholl, M. J. Accelerated Learning. Bandung: Nuansa. 2002

[17] Deporter, B. dan Hernacki, M. Quantum Learning. Bandung: Kaif. 2016

[18] A. Asrial, S. Syahrial, D. A. Kurniawan, M. Subandiyo, and N. Amalina, "Exploring Obstacles in Leanguage Learning Among Prospective Primay School Teacher," International Journal of Evaluation and Research in Education, vol. 8, no. 2, pp. 249-254, 2019 